\title{
Effect of deoxypyridoxine on signs of pyridoxine deficiency and intestinal 5-hydroxytryptamine
}

\author{
By D. J. BOULLIN* \\ Department of Pharmacology and Therapeutics, Queen's College, Dundee
}

(Received I6 December I963-Accepted I9 March 1964)

Many experiments have been devised to study the physiological significance of 5 -hydroxytryptamine. To do so, it has often been desirable to deplete organs of the amine, and the Rauwolfia alkaloid reserpine has been commonly used for this purpose. Though reserpine is capable of producing a severe depletion of 5-hydroxytryptamine in brain (Brodie, Pletscher \& Shore, I955) and intestine (Pletscher, Shore \& Brodie, I955; Bülbring \& Crema, I959), amongst other tissues, synthesis of the amine remains unimpaired, with the result that the depletion induced by reserpine is never absolute. To overcome this difficulty it has been necessary to use other methods, including nutritional methods, to prevent synthesis of 5-hydroxytryptamine. Theoretically this can be done in several ways: decarboxylase inhibitors, such as 3,4-dihydroxyphenyl$\alpha$-methylalanine ( $\alpha$-methyldopa), can be used to interfere with the enzymic conversion of the amino-acid precursor 5-hydroxytryptophan into 5-hydroxytryptamine by 5-hydroxytryptophan decarboxylase; a pyridoxine-deficient diet can be given as the enzyme 5-hydroxytryptophan decarboxylase is pyridoxine-dependent (Buxton \& Sinclair, 1956; Buzard \& Nytch, 1957), or a tryptophan-free diet can be given.

This paper describes some unsuccessful attempts at preventing 5-hydroxytryptamine synthesis by giving a pyridoxine-deficient diet with deoxypyridoxine. As reported elsewhere (Boullin, 1963, 1964) attempts with a tryptophan-free diet were successful and resulted in apparently complete depletion of 5 -hydroxytryptamine in some instances.

\section{EXPERIMENTAL AND RESULTS}

Animals. Litter-mate male Sprague-Dawley rats were used (weight $30-6 \circ \mathrm{g}$ ). They were segregated into pairs of equal weight $( \pm 10 \%)$; one rat of each pair was given a pyridoxine-deficient diet ad lib. while its litter-mate was pair-fed on an identical diet with the addition of $80 \mu \mathrm{g}$ pyridoxine hydrochloride daily.

Pyridoxine-deficient diet. The diet used was essentially that described by Boullin (I96I) except that pyridoxine hydrochloride was omitted and thiamine hydrochloride included. Additionally, deoxypyridoxine was given as a dose of 70 or $280 \mu \mathrm{g} /$ rat daily, in Expts. 2 and 3 respectively, to both deficient and control animals.

Skin lesions. The presence of typical skin lesions or 'rat acrodynia' (György, 1935; Birch, György \& Harris, 1935), together with loss of body-weight, was used as an

- Present address: Laboratory of Chemical Pharmacology, National Heart Institute, National Institutes of Health, Bethesda, Maryland 20014, USA. 
indication of the pyridoxine-deficiency state. The skin lesions were arbitrarily divided into three grades of severity: slight $(+)$, erythema of dorsa of hind paws, spreading to the plantae, with hyperkeratosis and scaling; moderate $(++)$, as above with the addition of swollen digits and mild lesions at mucocutaneous junctions; severe $(+++)$, exacerbation of the aforementioned signs and development of similar lesions on ears and tail.

Intestinal 5-hydroxytryptamine. 5-Hydroxytryptamine was extracted from the mucosal layer of the entire small intestine by the method described by Boullin (1963) and portions of the extract were assayed biologically for 5-hydroxytryptamine activity on a rat stomach preparation by the method of Vane (1957).

Expt 1 . In the first experiment thirty rats received the pyridoxine-deficient diet without deoxypyridoxine for 66-8I days (mean 72 days). They gained weight for the first few days, but growth then ceased. The maximal body-weight attained was significantly lower, at the I \% level, than that of the pair-fed controls, even though the total food intake was virtually identical (Table I).

Table I. Effect of deoxypyridoxine on body-weight and food intake of pyridoxine-deficient and control rats

\begin{tabular}{|c|c|c|c|c|c|c|c|c|c|}
\hline \multirow{3}{*}{$\begin{array}{c}\text { Expt } \\
\text { no. }\end{array}$} & \multirow{3}{*}{$\begin{array}{c}\text { Deoxy- } \\
\text { pyri- } \\
\text { doxine } \\
\text { intake } \\
(\mu \mathrm{g} / \text { day })\end{array}$} & & \multicolumn{6}{|c|}{ Body-weight (g) } & \multirow{3}{*}{$\begin{array}{c}\text { Mean food } \\
\text { intake } \\
\text { (g/day) } \\
D \text { and } C\end{array}$} \\
\hline & & & \multicolumn{2}{|c|}{ Initial } & \multicolumn{2}{|c|}{ Maximum } & \multicolumn{2}{|c|}{ Final } & \\
\hline & & & $\mathrm{D}$ & $\mathrm{C}$ & D & $\mathrm{C}$ & D & $\mathrm{C}$ & \\
\hline $\mathbf{I}$ & o & SE & $\begin{array}{c}54 \cdot 6 \\
\pm 1 \cdot 71\end{array}$ & $\begin{array}{c}53 \cdot 4 \\
\pm 1 \cdot 45\end{array}$ & $\begin{array}{r}86.0^{*} \\
\pm 1.77\end{array}$ & $\begin{array}{l}103.51 \dagger \\
\pm 2.22\end{array}$ & $\begin{array}{r}65.5 \\
\pm 1.25\end{array}$ & $\begin{array}{r}92 \cdot 3 \\
\pm 3 \cdot 64\end{array}$ & $4 \cdot 5$ \\
\hline 2 & 70 & $\mathrm{SE}$ & $\begin{array}{c}57 \cdot I \\
\pm I \cdot I 4\end{array}$ & $\begin{array}{c}56 \cdot 2 \\
\pm 1 \cdot 19\end{array}$ & $\begin{array}{r}75.1 \dagger \\
\pm 2.05\end{array}$ & $\begin{array}{c}89 \cdot 7 \\
\pm 2 \cdot 19\end{array}$ & $\begin{array}{c}60.3 \\
\pm 2 \cdot 64\end{array}$ & $\begin{array}{c}82 \cdot 1 \\
\pm 2.54\end{array}$ & $4 \cdot 6$ \\
\hline 3 & 280 & SE & $\begin{array}{c}52 \cdot 0 \\
\pm 1 \cdot 17\end{array}$ & $\begin{array}{c}52.7 \\
\pm 1.08\end{array}$ & $\begin{array}{r}71 \cdot 0 \dagger \\
\pm 2.31\end{array}$ & $\begin{array}{c}8 I \cdot 4 \\
\pm 3 \cdot 12\end{array}$ & $\begin{array}{c}56 \cdot 1 \\
\pm 2 \cdot 26\end{array}$ & $\begin{array}{c}79.2 \\
\pm 3.00\end{array}$ & 5.7 \\
\hline
\end{tabular}

D, pyridoxine-deficient; C, pair-fed litter-mate control.

* Value significantly greater at $\mathrm{I} \%$ level than values marked $\dagger$ and significantly less, at I $\%$ level, than value marked $+\dagger$.

Table 2. Effect of deoxypyridoxine added to the diet on incidence and severity of signs of pyridoxine deficiency in rats given a pyridoxine-deficient diet

Percentage of rats showing deficiency signs

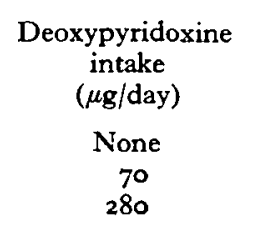

No. of
animals*
30
16
29

$\begin{array}{rrrrr}\overbrace{\text { None }}+\underbrace{}_{+++++} & & \\ \text {Skin lesionst } & & \\ 10 & 0 & 20 & 70 & 0 \\ 0 & 0 & 31 & 69 & 0 \\ 45 & 10 & 28 & 17 & 3\end{array}$

* All deficient animals duplicated by pair-fed controls.

+ For grading of skin lesions see above.

The incidence of skin signs is given in Table 2. Lesions eventually appeared in $90 \%$ of the deficient group, though not before at least I month. As the pharmacological responses of isolated tissues were normal (Boullin, unpublished observations), and no 
convulsions evident, it seemed likely that the deficiency was not particularly severe, so intestinal 5-hydroxytryptamine was not estimated.

Expt 2. For the second experiment $70 \mu \mathrm{g} /$ day deoxypyridoxine were included in the diets given to sixteen rats for $36-40$ days (mean 38 days). Inclusion of the antivitamin resulted in a maximal body-weight that was significantly lower, at the I\% level, than that seen in deficient rats which were not given deoxypyridoxine. However, this difference was not due to a reduction in food intake (Table I). Deoxypyridoxine had the expected effect of increasing the incidence and severity of skin lesions, so that all rats now showed some degree of acrodynia, though there were still no convulsions. When intestinal 5-hydroxytryptamine was measured in seven deficient and seven control rats, there was no significant difference, at the $5 \%$ level, between the values ('Table 3).

Table 3. 5-Hydroxytryptamine content of mucosa of the small intestine of pyridoxine-deficient and control rats given deoxypyridoxine

\begin{tabular}{|c|c|c|c|c|c|}
\hline \multirow{2}{*}{$\begin{array}{l}\text { Deoxypyridoxine } \\
\text { intake }(\mu \mathrm{g} / \text { day })\end{array}$} & \multicolumn{2}{|c|}{$\begin{array}{l}\text { 5-Hydroxytryptamine } \\
\text { content }(\mu \mathrm{g} / \mathrm{g})\end{array}$} & \multirow{2}{*}{$\begin{array}{l}\text { Deoxypyridoxine } \\
\text { intake }(\mu \mathrm{g} / \text { day })\end{array}$} & \multicolumn{2}{|c|}{$\begin{array}{l}5 \text {-Hydroxytryptamine } \\
\text { content }(\mu \mathrm{g} / \mathrm{g})\end{array}$} \\
\hline & D & C & & D & C \\
\hline 70 & $\begin{array}{l}2 \cdot 04 \\
3 \cdot 14 \\
4 \cdot 24 \\
1 \cdot 07 \\
6 \cdot 19 \\
4 \cdot 29 \\
6 \cdot 04\end{array}$ & $\begin{array}{l}2.92 \\
2.86 \\
3.81 \\
2.46 \\
6.80 \\
5.70 \\
5 \cdot 38\end{array}$ & 280 & $\begin{array}{l}2 \cdot 10 \\
2.50 \\
3.28 \\
3.37 \\
2.02 \\
2.36 \\
2.00\end{array}$ & $\begin{array}{l}2 \cdot 00 \\
2 \cdot 80 \\
3.76 \\
3.27 \\
4.96 \\
8 \cdot 45 \\
2 \cdot 43\end{array}$ \\
\hline $\begin{array}{l}\text { Mean } \\
\text { SE } \\
P\end{array}$ & $\begin{array}{r}3.86 \\
\pm 0.73\end{array}$ & $\begin{array}{r}4.28 \\
\pm 0.64 \\
.05\end{array}$ & $\begin{array}{l}\text { Mean } \\
\text { SE } \\
P\end{array}$ & $\begin{array}{r}2.52 \\
\pm 0.23\end{array}$ & $\begin{aligned} & 3.95 \\
& \pm 0.84 \\
&>0.05\end{aligned}$ \\
\hline
\end{tabular}

Expt 3. A third experiment was therefore carried out with twenty-nine rats given $280 \mu \mathrm{g} /$ day deoxypyridoxine for $26-58$ days (mean 32 days). This high level of antivitamin resulted in a further, but slight, reduction in the maximal body-weight (Table I). However, the average daily food intake was higher; there was certainly no evidence of anorexia in these deficient rats.

Regarding the effect of $280 \mu \mathrm{g} /$ day deoxypyridoxine on the incidence of skin lesions and intestinal 5-hydroxytryptamine, the results were most unexpected. Instead of an increase in acrodynia, there was in fact a decrease, nearly half the animals being free from signs, and again there was no significant depletion of intestinal 5 -hydroxytryptamine in the deficient group compared with the controls (Table 3 ).

\section{DISCUSSION}

Although these results were disappointing inasmuch as there was no depletion of intestinal 5-hydroxytryptamine, their interest, from a nutritional standpoint, lies in this failure and the apparent lack of correlation between the several signs commonly associated with the pyridoxine-deficiency state. Young animals are known to be especially susceptible to lack of pyridoxine, and, as other workers (e.g. Beaton \& 
McHenry, 1953) have shown that deficiency is aggravated by deoxypyridoxine, it was most surprising to find that the higher level of deoxypyridoxine did not exacerbate the signs of deficiency, but rather had the reverse effect. There seems no obvious explanation of this result.

It is quite clear from this and previous work that the effects of pyridoxine deficiency on decarboxylating enzymes depend on the organ and species from which the enzymes are obtained. Blaschko, Carter, O'Brien \& Stanley (1948) showed, in rats, that pyridoxine deficiency depressed liver DOPA decarboxylase, and Blaschko et al. (1948) and Blaschko, Datta \& Harris (1953) found that L-cysteic acid decarboxylase virtually disappeared. Pogrund, Drell \& Clark (1961) confirmed this result, but then found that kidney DOPA decarboxylase was but little affected. Furthermore, in pyridoxine-deficient rats bearing a transplantable hepatoma ( $\mathrm{F}-\mathrm{Hep}$ ), normal histidine decarboxylase activity was detected in the rapidly growing malignant tissue (Boullin, MacKay, Marshall \& Riley, 1961).

Considering the effects of pyridoxine deficiency on tissue 5-hydroxytryptamine levels, the first report (Weissbach, Bogdanski, Redfield \& Udenfriend, 1957) was encouraging as there were big reductions in brain, liver, blood and intestinal 5 -hydroxytryptamine in chickens. It has not, however, proved possible to obtain a severe depletion in the rat, possibly owing to variations in coenzyme-apoenzyme affinity relationships of the various decarboxylating enzymes between species. Thus Yeh, Solomon \& Chow (1959) reported only slight reductions in rat brain, liver and spleen, and the work discussed now indicates that rat intestine is also resistant to depletion.

The results of the small number of experiments giver in Table 3 indicate, however, that there was a trend towards lower values on the part of the deficient rats, though this was not statistically significant by the $t$ test (Student). Analysis of variance between the deficient groups given 70 and $280 \mu \mathrm{g}$ deoxypyridoxine daily showed that the variance of the latter group was significantly less, at the $\mathrm{I} \%$ level, than that of the former. This difference appeared to be due to the inability of the deficient rats to attain values comparable to those of their litter-mate controls when the latter were high (e.g. 2.02 compared with $4.96 \mu \mathrm{g} / \mathrm{g} ; 2.36$ compared with $8.45 \mu \mathrm{g} / \mathrm{g}$., Table 3 ). Consequently, though more experiments might have shown a significant depletion of intestinal 5-hydroxytryptamine, it seems improbable that the degree of depletion would have compared with that seen in chickens (Weissbach et al. 1957), or in rats given a tryptophan-free diet (Boullin, 1963, 1964).

It is concluded that a pyridoxine-deficient diet, even with addition of deoxypyridoxine, did not greatly influence production of 5 -hydroxytryptamine in rat intestinal mucosa.

\section{SUMMARY}

I. Male Sprague-Dawley rats were fed on a pyridoxine-deficient diet alone or with 70 or $280 \mu \mathrm{g}$ deoxypyridoxine daily; litter-mate controls were pair-fed on an identical diet with pyridoxine hydrochloride.

2. Of the rats given the deficient diet alone $70 \%$ showed severe acrodynia. Intestinal 5-hydroxytryptamine was not estimated. 
3. When $70 \mu \mathrm{g}$ deoxypyridoxine/day were given there was increased incidence and severity of acrodynia, but there was no significant depletion of the 5-hydroxytryptamine in the mucosa of the small intestine.

4. When $280 \mu \mathrm{g}$ deoxypyridoxine were given daily, almost $50 \%$ of the animals were free of acrodynia and again there was no significant depletion of intestinal 5-hydroxytryptamine.

\section{REFERENCES}

Beaton, G. H. \& McHenry, E. W. (1953). Brit. F. Nutr. 7, 357.

Birch, T. W., György, P. \& Harris, L. J. (1935). Biochem. F. 29, 2830.

Blaschko, H., Carter, C. W., O'Brien, J. R. P. \& Stanley, G. H. S. (1948). J. Physiol. 107, 18 P.

Blaschko, H., Datta, S. P. \& Harris, H. (1953) Brit. F. Nutr. 7, 364.

Boullin, D. J. (1961). Brit. Y. Nutr. 15, 577.

Boullin, D. J. (1963). Psychopharmacologia (Berl.), 5, 28.

Boullin, D. J. (1964). Brit. Y. Pharmacol. (In the Press.)

Boullin, D. J., MacKay, D., Marshall, P. B. \& Riley, J. F. (196r). Brit. Y. Pharmacol. 17, 1.

Brodie, B. B., Pletscher, A. \& Shore, P. A. (1955). Science, 122, 968.

Bülbring, E. \& Crema, A. (1959). F. Physiol. 146, 29.

Buxton, J. \& Sinclair, H. M. (1956). Biochem. F. 62, 27 P.

Buzard, J. A. \& Nytch, P. D. (1957). Y. biol. Chem. 229, 409.

György, P. (1 935). Biochem. Y. 29, 74I.

Pletscher, A., Shore, P. A. \& Brodie, B. B. (1955). Science, 122, 374.

Pogrund, R. S., Drell, W. \& Clark, W. G. (196I). F. Pharmacol. exp. Ther. 131, 294.

Vane, J. R. (1957). Brit. F. Pharmacol. 12, 344.

Weissbach, H., Bogdanski, D. F., Redfield, B. G. \& Udenfriend, S. (1957). F. biol. Chem. $227,617$.

Yeh, S. D. J., Solomon, J. D. \& Chow, B. F. (1959). Fed. Proc. 18, 357. 